\title{
Effect of Gender on Lung Function and Patient-Reported Outcomes in Patients with COPD Receiving Nebulized Glycopyrrolate [Corrigendum]
}

Ohar JA, Ozol-Godfrey A, Goodin T, Sanjar S. Int J Chron Obstruct Pulmon Dis. 2020;15:995-1004.

The authors have advised there is an error in Figure 4B on page 1000. For EXACT-RS responder rates, the OR for both genders are shown to be significant at $\mathrm{p}<0.05$; however, the OR is significant only in males. The correct Figure 4 is shown below.

The authors apologize for this error.

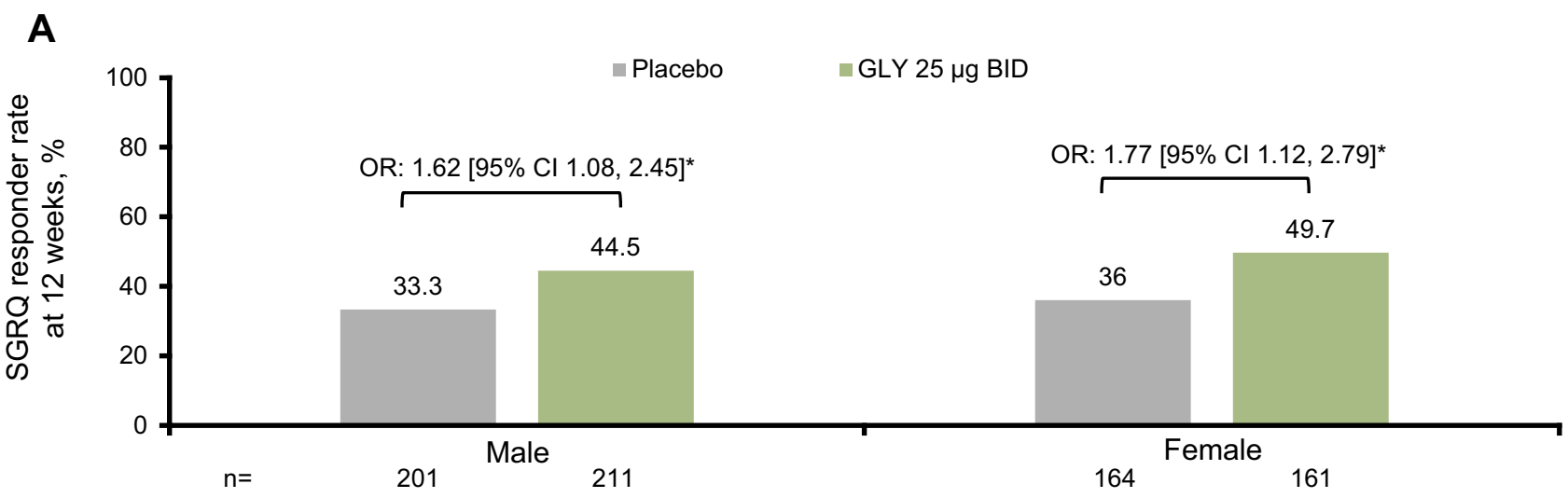

B

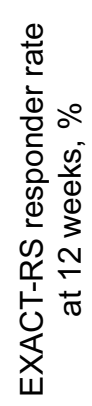

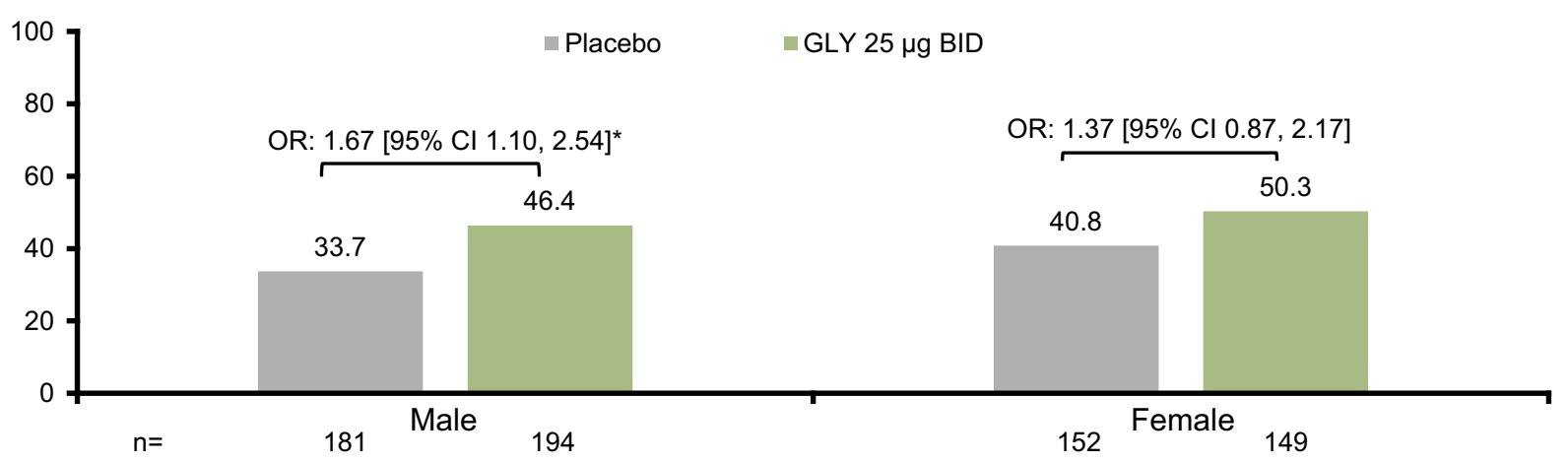

Figure 4 Pooled analysis of (A) SGRQ responder rates, (B) EXACT-RS responder rates at 12 weeks, by gender (ITT population).

Note: $*^{*}<0.05$ vs placebo.

Abbreviations: BID, twice daily; Cl, confidence interval; EXACT-RS, EXAcerbations of COPD Tool-Respiratory Symptoms; GLY, nebulized glycopyrrolate; ITT, intentto-treat; OR, odds ratio; SGRQ, St George's Respiratory Questionnaire. 


\section{Publish your work in this journal}

The International Journal of COPD is an international, peer-reviewed journal of therapeutics and pharmacology focusing on concise rapid reporting of clinical studies and reviews in COPD. Special focus is given to the pathophysiological processes underlying the disease, intervention programs, patient focused education, and self management protocols. This journal is indexed on PubMed Central, MedLine and CAS. The manuscript management system is completely online and includes a very quick and fair peer-review system, which is all easy to use. Visit http://www.dovepress.com/testimonials.php to read real quotes from published authors.

Submit your manuscript here: https://www.dovepress.com/international-journal-of-chronic-obstructive-pulmonary-disease-journal

https://doi.org//0.2147/COPD.S317916 